University for Business and Technology in Kosovo

UBT Knowledge Center

UBT International Conference

2018 UBT International Conference

Oct 27th, $10: 45$ AM - 12:15 PM

\title{
Occurrence of ochratoxin A in food commodities consumed in Prishtina market
}

\author{
Jeton Spahiu \\ Justus Liebig University, jetonspahiu1@gmail.com \\ Driton Topis \\ University of Tirana \\ Manfred Gareis \\ Ludwig-Maximilian University of Munich \\ Adem Rama \\ Higher Colleges of Technology, Abu Dhabi \\ Kurtesh Sherifi \\ University of Prishtina
}

Follow this and additional works at: https://knowledgecenter.ubt-uni.net/conference

Part of the Food Science Commons

\section{Recommended Citation}

Spahiu, Jeton; Topis, Driton; Gareis, Manfred; Rama, Adem; and Sherifi, Kurtesh, "Occurrence of ochratoxin A in food commodities consumed in Prishtina market" (2018). UBT International Conference. 183.

https://knowledgecenter.ubt-uni.net/conference/2018/all-events/183

This Event is brought to you for free and open access by the Publication and Journals at UBT Knowledge Center. It has been accepted for inclusion in UBT International Conference by an authorized administrator of UBT Knowledge Center. For more information, please contact knowledge.center@ubt-uni.net. 


\title{
Occurrence of ochratoxin A in food commodities consumed in Prishtina market
}

\author{
Jeton Spahiu ${ }^{1,4}$, Dritan Topi ${ }^{5}$, Manfred Gareis ${ }^{2}$, Adem Rama ${ }^{3}$, Kurtesh Sherifi ${ }^{4}$ \\ ${ }^{1}$ Institute of Nutritional Sciences, Justus Liebig University, 35390, Giessen, \\ Germany \\ ${ }^{2}$ Faculty of Veterinary Medicine, Ludwig-Maximilian University of Munich, 85764 \\ Oberschleissheim, Germany \\ ${ }^{3}$ Higher Colleges of Technology, Abu Dhabi, United Arab Emirates \\ ${ }^{4}$ Faculty of Agriculture and Veterinary Medicine, University of Prishtina, 10000 \\ Prishtina, Kosovo \\ ${ }^{5}$ University of Tirana, Faculty of Natural Sciences, Albania \\ jeton.spahiu@agrar.uni-giessen.de;
}

\begin{abstract}
Ochratoxin A (OTA), is a mycotoxin, produced by a number Aspergillus species and Penicillium verrucosum, can be found in several food commodities including cereals, wine, coffee, cacao, spices or dried fruits, milk, meat resulting in a chronic human exposure. According to the toxicological studies, OTA has been shown to be nephrotoxic, hepatotoxic, teratogenic and immunotoxic to animals and human. It is a regulated mycotoxin and maximum limits in a wide range of foodstuffs have been established by Commission Regulation (EC) No 1881/2006. . The aim of our study was to investigate the presence of OTA in cereal derived products and roasted coffee beans and ground roasted beans from Prishtina market. A total of 112 samples were collected from different markets and traditional bazaars during 2016-2017 years, according to the sampling method for the official control of Ochratoxin A laid down in Commission Regulation (EC) No 401/2006. The analytical methods used in this study involved Liquid Chromatography coupled with Tandem Mass Spectrometry (LC-MS-MS). Our findings show that contamination levels of OTA in all cereal-derived products were lower than the permitted level by European Commission Regulation and Kosovo Food Codex. The frequencies of OTA contamination were $11.62 \%, 10.05 \%$ and $5.95 \%$ and the mean concentrations of positive samples were $0.72 \mu \mathrm{g} / \mathrm{kg}, 0.84 \mu \mathrm{g} / \mathrm{kg}, 0.41 \mu \mathrm{g} / \mathrm{kg}$ for maize flour, wheat-flour, and coffee samples, respectively.
\end{abstract}

Keywords: Ochratoxin A, maize flour, wheat flour, coffee, LC-MS/MS, Public health Kosovo

\section{Introduction}

Ochratoxin A, sometimes named OTA is naturally toxin created by fungal species of the genus Penicillum and Aspergillus (1).

OTA is known as a mycotoxin of stored productts and has strongly linked with Human endemic nepropathy (BEN), and Porcine nepropathy through ingestion of contaminated food and feed with OTA $(4,5)$. 
With OTA can be contaminated a large of variety of food products including cereals, cereal by products, wine, coffee, milk, spices, dried fruits, rice, green tea, figs, vegetables, beer etc ( 7,8 , 9)

The most toxic of the group of ochratoxins is OTA, and is classified as potecial carcinogen at humans (2B group) evaluated by International Agency for research on Cancer $(2,1)$.

Kosovo Parliament has approved the regulation on contaminats (3) which is in whole text harmonised with European Commission Regulation 1881/2006, where both institutions have set the maximum allowed limit of $3 \mu \mathrm{g} / \mathrm{kg}$.and $5 \mu \mathrm{g} / \mathrm{kg}$, for cereal derivatives and for roasted coffee, respectively.

In 10 anniversary of independence, we are still trying to create capacities to monitor the food in the market and have a safer food in our table, to protect public health. The aim of this investigation was to have a mirror of contamination of food marketed in Prishtina. Our study was performed in two years of periods continously 2016-2017.

\section{Sampling}

Sampling places in this investigation were chosen randomly from different markets, supermarkets, restaurants, bakeries, flour-mills, traditional bazzars etc. during 20162017 years. Cereal by products samples were collected in mostly in flour-mills, but some of the samples were collected also in the bakeries during 2016, in the total 70 samples. For coffee, were collected 42 samples during 2017 also in the Prishtina city. Representative subsamples (10 g) were collected and used in the study. Sampling procedure was done in the harmony with European Commmission regulation 401/2006 (European Commission 2006a). Samples was stored in proper conditions $-18^{0} \mathrm{C}$ until analysed by LC MS MS at Food and Veterinary Laboratory, in Prishtina.

\section{Sample preparation for Elisa}

For Cereals: Grind and mix a representative sample, weigh out $5 \mathrm{~g}$ of ground sample and place into a falcon tube $15 \mathrm{ml}$, add $25 \mathrm{ml}$ of $70 \%$ ethanol and shake for $20 \mathrm{~min}$. with a shaker then centrifuge sample for $10 \mathrm{~min}$. At $4.000 \mathrm{rpm}$, after dilute $1 \mathrm{ml}$ of the obtained supernatant with 1 $\mathrm{ml}$ of distilled water, following step is disturbing $50 \mu \mathrm{l}$ in every microwell in the plate, in double. For roasted coffee: Grind and mix a representative sample, weigh $5 \mathrm{~g}$ of sample and put into a soluble container, added $25 \mathrm{ml}$ of $70 \%$ ethanol and shake for $20 \mathrm{~min}$. In a shaker, after this step followed by centrifugation of sample for $10 \mathrm{~min}$ at $4.000 \mathrm{rpm}$, diluting of $50 \mu \mathrm{l}$ of the obtained supernatant with $950 \mu \mathrm{l}$ of a 35:65 mixture of ethanol/deionized $\mathrm{H} 2 \mathrm{O}$.

\section{Testing protocol according to manufacturer instructions}

First step is to add $50 \mu 1$ of each Standards in duplicate into different microwells, after add $50 \mu \mathrm{l}$ of each sample in duplicate into different microwells, followed by adding $100 \mu \mathrm{l}$ of antibody 1 and mix well by gently rocking the plate manually for $1 \mathrm{~min}$. While incubating period is $30 \mathrm{~min}$ at room temperature, following step is to wash 3 times with $250 \mu \mathrm{l}$ of $1 \mathrm{X}$ Wash Solution. After the last wash, invert the plate and gently tap the plate dry on paper towels, add $100 \mu$ l of Antibody 2 solution, and then the next step is incubating the plate for 30 $\mathrm{min}$. At room temperature, wash the plate 3 time as the same procedure as washing procedure above, add $100 \mu \mathrm{l}$ of TMB substrate, after incubating $15 \mathrm{~min}$. At room temperature, add $100 \mu \mathrm{l}$ of Stop Solution to stop the enzyme reaction, the last step is reading the plate at $450 \mathrm{~nm}$ wavelength.

\section{Chemicals and standards}


Ochratoxin A standard was purchased from Cayman (USA), Immunoaffinity columns MycoSep 229 Ochra were obtained from Romer Lab (Asustria).

Methanol $(\mathrm{MeOH})$, Acetonitrile $(\mathrm{ACN})$, auas ammonia were supplied from LAB SCAN Ltd (Dublin, Ireland).

\section{Determination of OTA}

The procedure for OTA extraction from cereals by products is described as follow:

Clean-up: $5 \mathrm{~mL}$ from the filtrate were diluted with $40 \mathrm{~mL}$ PBS and mixed for $30 \mathrm{sec}$. Solution was loaded in the MycoSep 229 Ochra column (flow rate $3 \mathrm{~mL} \mathrm{~min}-1$ ) and washed once with 10 $\mathrm{mL}$ of water. The column allowed to dry by passing air through it. OTA was eluted with $3 \mu \mathrm{L}$ of a solution of methanol. The eluate was then evaporated to dryness under a gentle stream of nitrogen. The residue was dissolved immediately in $500 \mu \mathrm{l}$ mobile phase and an aliquot was kept at $-18^{\circ} \mathrm{C}$ for the confirmation of the analysis.

\section{Results and Discution}

Table 1. The results of OTA contamination in foodcommodities marketed in Prishtina

\begin{tabular}{|c|c|c|c|c|c|c|c|}
\hline & \multicolumn{4}{|c|}{$\mathrm{n}$ contaminated $/ \mathrm{n}$ samples } & \multicolumn{3}{|c|}{ Mean + SD of the conc. of OTA $\mu \mathrm{g} / \mathrm{kg}$} \\
\hline $\begin{array}{c}\text { Municipality / } \\
\text { Year }\end{array}$ & Maize flour & $\begin{array}{l}\text { Wheat } \\
\text { flour }\end{array}$ & Coffee & Total & $\begin{array}{l}\text { Maize } \\
\text { flour }\end{array}$ & $\begin{array}{l}\text { Wheat } \\
\text { flour }\end{array}$ & Coffee \\
\hline Prishtina & & & & & & & \\
\hline 2016 & $\begin{array}{c}2 / 17 \\
(11.62 \%)\end{array}$ & $3 / 30(10.0 \%)$ & $1 / 30(3.33 \%)$ & 6/77(7.8\%) & $0.721 \pm 0.112$ & $0.777 \pm 0.141$ & $0.321 \pm 0.154$ \\
\hline 2017 & $0 / 3(0.0 \%)$ & $2 / 20(10.0 \%)$ & $1 / 12(8.33 \%)$ & $3 / 35(8.6 \%)$ & 0 & $0.981 \pm 0.112$ & $0.521 \pm 0.251$ \\
\hline Prishtina Total & $2 / 20(11.62 \%)$ & $5 / 50(10.0 \%)$ & $2 / 42(5 . .95 \%)$ & $9 / 112(8.04 \%)$ & $0.721 \pm 0.112$ & $0.847 \pm 0.112$ & $0.421 \pm 0.181$ \\
\hline
\end{tabular}

General: A total of 112 foodcommodities samples including 77 from 2016 and 35 from 2017 were analysed for OTA.

Ochratoxin A in maize flour and wheat flour collected from the Prishtina Market were generally in low level.

In total, $8 \%$ (6/77 samples) from the samples collected in 2016 were contaminated, while $9 \%$ (3/35 samples) from 2017 were contaminated with ochratoxin A. The mean concentration of OTA in wheat flour samples were $0.78 \mu \mathrm{g} / \mathrm{kg}$, in maize flour $0.72 \mu \mathrm{g} / \mathrm{kg}$ and in coffee $0.32 \mu \mathrm{g} / \mathrm{kg}$ during 2016, whereas in 2017, in the coffee samples was $0.52 \mu \mathrm{g} / \mathrm{kg}$, in maize flour samples was 0 and in wheat flour samples was $0.98 \mu \mathrm{g} / \mathrm{kg}$.

The highest level was in maize flour samples with $1.1 \mu \mathrm{g} / \mathrm{kg}$.

In this investigation, 9 samples were contaminated with OTA, but none of them exceeded the maximum limit established by Kosovo Food Law and European Commission Regulation on OTA in cereal derivatives and roasted coffee of $3 \mu \mathrm{g} / \mathrm{kg}$ and $5 \mu \mathrm{g} / \mathrm{kg}$, respectively.

Previous scientific investigation done by (12) has confirmed of the presence of OTA in cereal flour contaminated samples in Prishtina region. But also none of the contaminated samples did not above the maximum limit set by Kosovo Food Law ( Official Journal of RKS, 2013) on cantaminants and European Commission Directives 1881/2006.

In the best of our knowledge, there is no investigation of OTA in coffee products marketed in Kosova, so this is the first investigation about of food safety on this foodcommodities. 
In Serbia, where more than $30 \%$ of our cereal comes from this country, some invstigation were done about OTA in cereal and cereal by products. Last year (10) has made an research investigation with the samples from 2012-2016, from 114 cereal samples, $10.7 \%$ maize samples were above the maximum limit set by Serbian Food Codex whereas another investigation were done in 2012 by (11), none of the samples analysed in this research did not exceed the ML.

In conclusion, OTA is not a huge hazard in our country according to our results, but the state agencies which are responsibles to monitor food safety should beginn to analyse for OTA in food commodities, further research is warranted and also to be a national plan of monitoring of mycotoxins including among OTA. Also, needs to be more collaboration between policymakers, bussinesses and consumers to increase of awarenes anf to apply good agricultural practices to reduce the risk from mycotoxins to have a safety food and better and longer life.

Acknowledgements

The project is part of Tempus Project "PhD in Food Science and Technology \& Creating Capacities for PhD Reform at the University of Prishtina - PhD@UP"

\section{References}

1. Bennett J.W., Klich M. Mycotoxins. Clin. Microbiol. Rev. 2003;16:497-516. doi: 10.112 8/CMR.16.3.497-516.2003

2. IARC. Some Naturally Occurring Substances: Food Items and Constituents, Heterocyclic Aromatic Amines and Mycotoxins. IARC Monographs on the Evaluation of Carcinogenic Risks to Humans; IARC: Lyon, France, 1993.

3. Regulation (GRK) No. 43/2013 Laying down maximum leveles of certain contaminants in foodstuffs and undesirable substances in animal feedingstuffs of the republic of Kosovo, Official Journal

4. Krogh, P., 1976, Epidemiology of mycotoxic porcine nehropathy. Nordisk Veternaemedicine, 28:452-458.

5. Plestina, R., 1996, Nephrotoxicity of ochratoxin A, Food Additives and Contaminants, 13 (suppl.):49-50.

6. European Food Safety Authority (EFSA). Opinion of the scientific panel on contaminants in the food chain on a request from the commission related to ochratoxin A in food. EFSA J. 2006, 365, 1-56.

7. Rizzo A., Eskola M., Atroshi F. Ochratoxin A in cereals, foodstuffs and human plasma. Eur. J. Plant Pathol. 2002;108:631-637. doi: 10.1023/A:1020683130901.

8. Jørgensen K. Occurrence of ochratoxin A in commodities and processed food-A review of EU occurrence data. Food Addit. Contam. 2005;S1:26-30. doi: $10.1080 / 02652030500344811$

9. Napolitano A., Fogliano V., Tafuri A., Ritieni A. Natural occurrence of ochratoxin A and antioxidant activities of green and roasted coffees and corresponding byproducts. J. Agric. Food Chem. 2007;55:10499-10504. doi: 10.1021/jf071959+.

10. Liilja Torović. (2017).Aflatoxins and ochratoxin A in flour: a survey of the Serbian retail market Food Additives $\ \&$ Contaminants.

11. Biljana Škrbić, Jelena Živančev, Nataša Đurišić-Mladenović, Michal Godula(2012); Principal mycotoxins in wheat flour from the Serbian market: Levels and assessment of the exposure by wheat-based products 2012 food control 10.1016/j.foodcont.2011.10.059. 
12. SPAHIU, Jeton et al. Level of ochratoxin A in cereal-flours in the Prishtina region.Phytopathologia Mediterranea, [S.1.], v. 57, n. 2, p. 341-350, sep. 2018.

ISSN 1593-2095. 